\title{
Ketersediaan dan Kualitas Airtanah pada Akuifer Tidak Tertekan di Keca- matan Jawilan dan Kopo, Kabupaten Serang
}

\author{
Ig.L.Setyawan Purnama
}

Fakultas Geografi, Universitas Gadjah Mada

Email Koresponden:Setyapurna@geo.ugm.ac.id

Diterima: 2018-09-14 /Refisi: 2018-10-05 Disetujui: 2019-02-01

(2019 Fakultas Geografi UGM dan Ikatan Geograf Indonesia (IGI)

\begin{abstract}
Abstrak Tujuan dari penelitian ini adalah (1) mengetahui sistem akuifer di daerah penelitian, (2) menghitung ketersediaan airtanah pada akuifer tidak tertekan dan (3) menganalisis kualitas airtanahnya. Sistem akuifer diketahui dengan melakukan interpretasi data geolistrik. Potensi akuifer tidak tertekan dihitung secara kualitatif melalui skoring dan tumpang susun antara Peta Kedalaman Muka Airtanah, Peta Fluktuasi Airtanah dan Peta Kualitas Airtanah. Volume akuifer ditentukan berdasarkan perkalian antara luas wilayah masing-masing potensi dan tebal akuifer. Ketersediaan airtanah dihitung berdasarkan asumsi aliran airtanah statik, sedangkan hasil aman pengambilan airtanah ditentukan berdasarkan parameter fluktuasi airtanah, luas akuifer dan spesifik yield. Kualitas airtanah dianalisis berdasarkan pengambilan sampel air secara purposive pada sumur gali. Hasil penelitian menunjukkan bahwa di daerah penelitian ditemukan adanya akuifer semi tertekan dan akuifer tidak tertekan. Ditinjau dari potensinya, ketersediaan airtanah pada akuifer tidak tertekan sebesar 1.205.967.345 m3, dengan hasil aman pengambilan airtanah sebesar $54.585 .307 \mathrm{~m} 3 /$ tahun. Untuk kualitas airtanah, secara umum baik, meskipun beberapa parameter seperti kalsium, magnesium, BOD dan COD kadarnya telah melampaui baku mutu di beberapa sampel.
\end{abstract}

Kata kunci: akuifer, airtanah, Kabupaten Serang.

Abstract The objectives of this study were (1) to know the aquifer system in the study area, (2) to calculate the availability of groundwater in unconfined aquifers and (3) to analyze the quality of groundwater. The aquifer system is known by interpreting geoelectric data. The potential of unconfined aquifers is calculated qualitatively through scoring and overlaying between Groundwater Depth Map, Groundwater Fluctuation Map and Groundwater Quality Map. Aquifer volume is determined based on the multiplication between the area of each potential and the thickness of the aquifer. Availability of groundwater is calculated based on the assumption of static groundwater flow, while the safe yield is determined based on parameters of groundwater fluctuations, aquifer area and specific yield. Groundwater quality was analyzed based on purposive sampling of water in the dug wells. The results showed that in the study area there were semi confined aquifers and unconfined aquifers. Base on its potential, the availability of groundwater in the unconfined aquifer is 1,205,967,345 m3, with safe yields $54,585,307$ m3/year. For groundwater quality, it is generally good, although some parameters have concentration exceeded the standard in some samples such as calcium, magnesium, BOD and COD.

Keywords: aquifer, groundwater, Serang Regency

\section{PENDAHULUAN}

Air adalah sumber primer kehidupan yang dibutuhkan untuk semua kegiatan manusia seperti kebutuhan domestik, pertanian dan industri (Purnama, 2012 ; Fenta \& Kifle, 2015). Dapat dikatakan bahwa air merupakan suatu berkah karena keberadaannya mempengaruhi kualitas hidup tiaptiap manusia (Fontana et al. 2008). Menurut Moench dan Barlow (2000), bertambahnya kebutuhan air terkait pertumbuhan penduduk menimbulkan adanya kesadaran dari masyarakat untuk mengelola keberadaan sumberdaya air yang jumlahnya terbatas. Airtanah merupakan bagian dari sumberdaya air yang paling penting (Naghibi \& Pourghasemi, 2015). Menurut Waikar dan Nilawar (2014), airtanah adalah juga merupakan salah satu sumberdaya alam yang berperan sangat penting untuk mendukung kesehatan manusia, pertumbuhan ekonomi dan keanekaragaman hayati. Keberadaan airtanah sangat tergantung dari keadaan geologi suatu daerah (Rushton, 2003; Kumar et al. 2016). Pengelolaan airtanah dimulai dengan memperhatikan daerah imbuhan. Air hujan yang jatuh di daerah tersebut akan mengalami infiltrasi. Pergerakan turun air yang meresap tersebut baru akan berhenti apabila terdapat lapisan kedap (impermeable) yang menghalanginya. Airtanah yang telah berada dalam lapisan akuifer tidaklah berada dalam keadaan diam, namun akan bergerak secara horisontal sesuai gradien hidroliknya, yaitu mengalir dari tempat yang muka airtanahnya lebih tinggi ke tempat yang muka airtanahnya lebih rendah. Berdasarkan Peta Geologi, kondisi geologi Kecamatan Jawilan dan Kopo yang terdapat di Kabupaten Serang bagian tenggara, didominasi oleh batuan volkanik, baik sebagai hasil aktivitas gunungapi tersier maupun kwarter tua. Diperkirakan di bagian selatan Kabupaten Serang pernah terdapat gunungapi yang cukup besar dan pernah meletus hebat membentuk kaldera, yang sekarang dikenal sebagai Rawa 
Danau. Saat ini sebagian besar Rawa Danau telah mengalami pendangkalan membentuk dataran aluvial, sedangkan sebagian kecil lainnya masih berupa rawa. Ditinjau dari batuannya, sebagian besar Serang Tenggara tersusun oleh aluvium dan tuf. Material aluvium berada pada topografi datar hingga landai dengan tekstur dominan lempung yang dihasilkan oleh endapan hasil proses denudasi gunungapi. Berdasarkan hidrogeologinya, Serang Tenggara merupakan bagian dari Cekungan Airtanah (CAT) Serang-Tangerang. Cekungan Airtanah ini merupakan cekungan airtanah terluas di Provinsi Banten, meliputi Kabupaten Tangerang, Kota Tangerang, Kota Serang, Kabupaten Serang, Kota Cilegon, sebagian Kabupaten Lebak dan sebagian Kabupaten Pandeglang. Terkait perkembangan wilayah, karena lokasinya yang strategis, Kabupaten Serang sebagai salah satu kabupaten di Provinsi Banten mengalami perkembangan yang cukup pesat. Terdapat indikasi terbangunnya kawasan industri yang diikuti dengan pembangunan perumahanperumahan baru di beberapa tempat sebagai dampak dari pertambahan penduduk. Kebutuhan akan sarana dan prasarana hidup dimungkinkan juga makin meningkat, termasuk kebutuhan air bersih. Di sisi lain imbuhan airtanah semakin berkurang akibat berkurangnya daerah resapan. Lahan-lahan terbuka yang semula berfungsi sebagai daerah peresapan air hujan ke dalam tanah telah berubah peruntukannya sebagai permukiman ataupun bangunan industri. Akibatnya ketersediaan airtanah dalam akuifer semakin berkurang dan bahkan terjadi penurunan muka airtanah. Terkait kualitasnya, ada kecenderungan bahwa seiring dengan semakin berkembangnya industri dan permukiman, semakin banyak pula limbah industri dan limbah rumah tangga yang dihasilkan dan mencemari airtanah. Berdasarkan latar belakang ini, tujuan dari penelitian ini adalah (1) mengetahui sistem akuifer di daerah penelitian dan (2) menghitung ketersediaan airtanah pada akuifer tidak tertekan dan (3) menganalisis kualitas airnya.

\section{METODE PENELITIAN}

Stratigrafi batuan dan sistem akuifer diketahui dengan melakukan pendugaan geolistrik di 10 titik pendugaan. Penentuan lokasinya dilakukan secara purposive dengan mempertimbangkan kondisi geologi wilayah (Gambar 1).

Karena ingin mengetahui perlapisan batuan secara vertikal, maka digunakan rangkaian Schlumberger (Gambar 2). Untuk itu, arus listrik searah dialirkan ke dalam tanah melalui elektroda besi dan diukur kuat arusnya dengan voltmeter, sedangkan perubahan nilai potensial tanah yang terjadi diukur dengan potensiometer melalui elektroda tembaga yang ditancapkan diantara kedua elektroda besi (Richards et al. 2010 ; Wamalwa et al. 2011). Dengan membagi

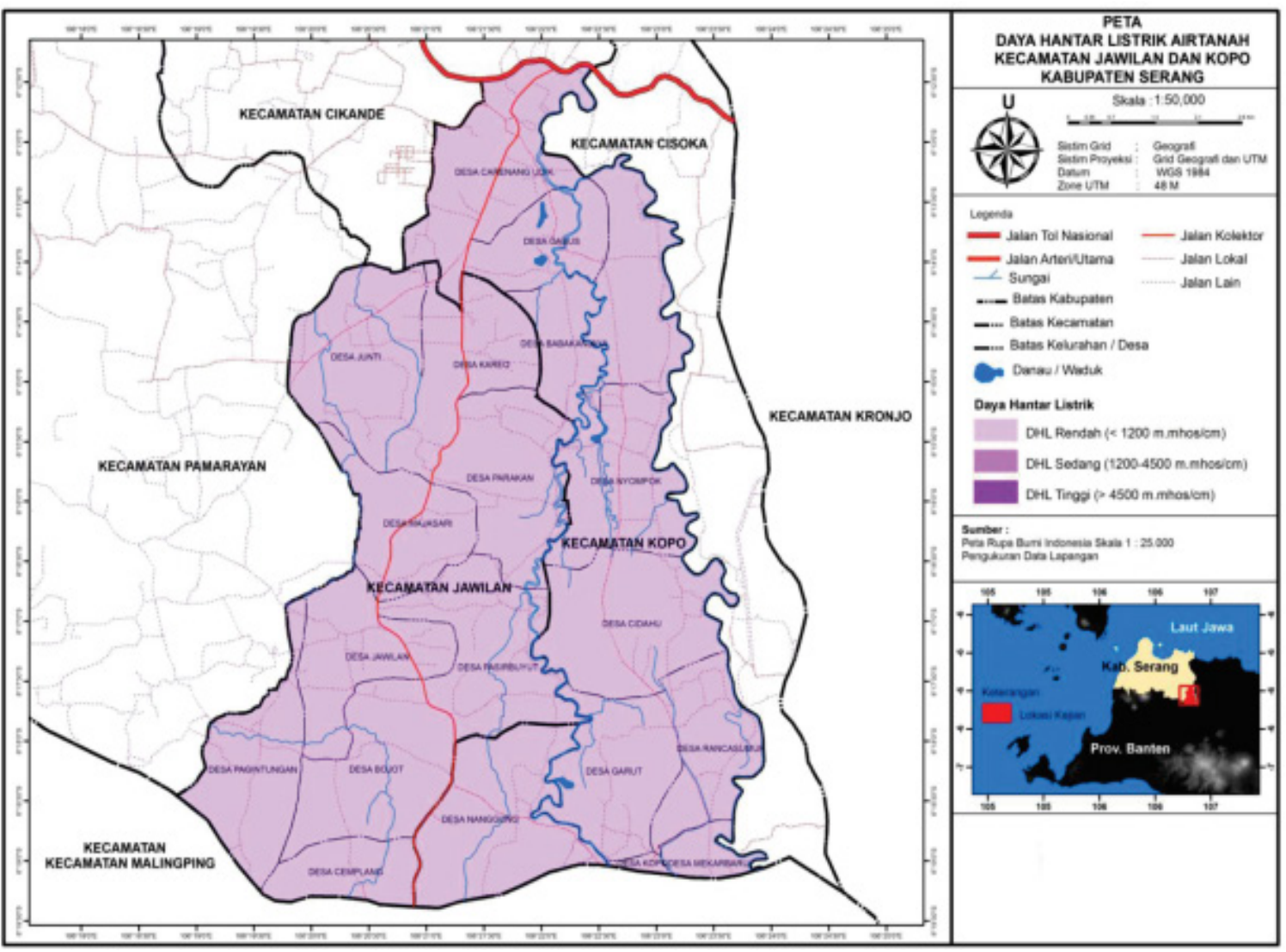

Gambar 1. Lintasan pendugaan geolistrik 


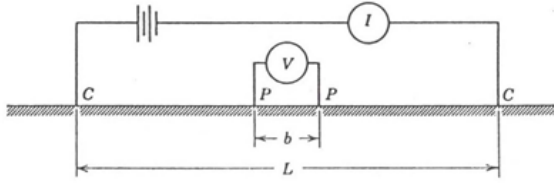

I : voltmeter

: potensiomete

$\mathrm{C}$ : elektroda arus

: jarak antar elektroda potensial

$\mathrm{P}$ : elektrode potensial
Tabel 1. Hasil analisis perlapisan batuan

\begin{tabular}{ll}
\hline Nilai Tahanan Jenis & Material Batuan \\
\hline$<5,0 \Omega \mathrm{m}$ & Tuf batupasir \\
$5,0-7,5 \Omega \mathrm{m}$ & $\begin{array}{l}\text { Campuran antara tuf dan } \\
\text { material aluvium }\end{array}$ \\
$>7,5 \Omega \mathrm{m}$ & $\begin{array}{l}\text { Material aluvium berupa } \\
\text { pasir dan lempung }\end{array}$ \\
\hline
\end{tabular}

Gambar 2. Rangkaian Schlumberger

(Todd \& Mays, 2005)

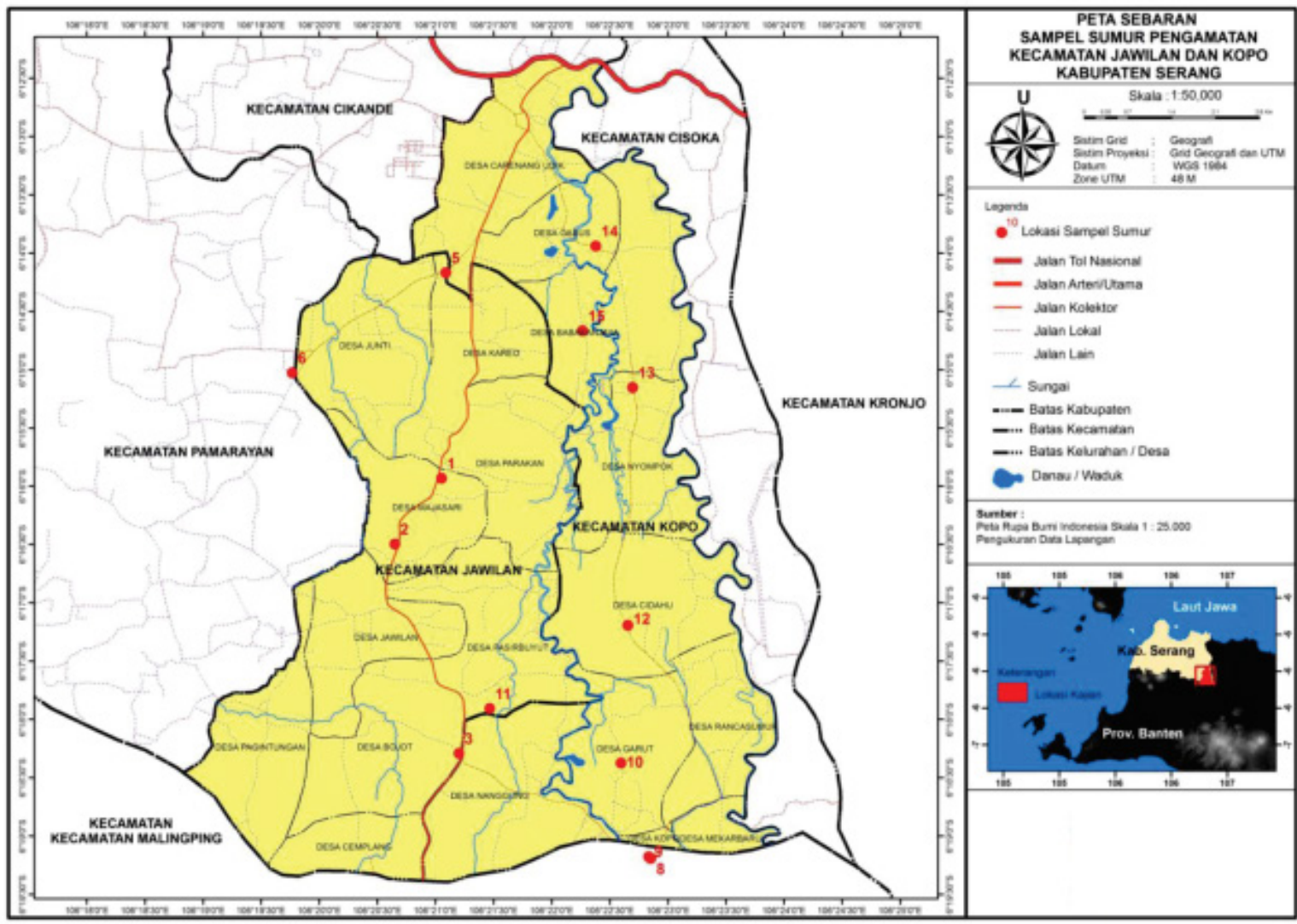

Gambar 3. Sebaran sampel sumur

nilai kuat arus dengan nilai potensial tanah dan kemudian mengalikannya dengan konstanta jarak elektoda akan dihasilkan nilai tahanan jenis batuan. Data tahanan jenis yang didapatkan dari pendugaan geolistrik di lapangan adalah data tahanan jenis semu (Zohdy et al. 1980 ; Todd \& Mays, 2005 ; Purnama, 2017). Nilai tahanan jenis aktual diperoleh melalui penafsiran data menggunakan software IP2WIN. Penentuan potensiakuifer didaerah penelitian dilakukan melalui metode skoring dan tumpang susun antara Peta Kedalaman Muka Airtanah, Peta Fluktuasi Airtanah dan Peta Kualitas Airtanah, yang dalam hal ini digunakan nilai daya hantar listrik (DHL) sebagai representasi banyaknya kadar ion dalam airtanah. Volume akuifer ditentukan berdasarkan perkalian antara luas wilayah masing-masing kelas potensi dengan tebal akuifer, sedangkan ketersediaan airtanah dihitung berdasarkan asumsi aliran airtanah statik (Purnama, 2010). Vat $=$ Sy $\mathrm{x}$ Vak dengan Vat adalah ketersediaan airtanah, Sy adalah spesifik yield dan Vak adalah volume akuifer. Karena Vak atau volume akuifer adalah hasil kali antara luas wilayah (A) dengan tebal akuifer (D), maka persamaan tersebut dapat ditulis menjadi : Vat $=$ Sy $\times$ A $\times$ D

Hasil aman (safe yield) pengambilan airtanah ditentukan berdasarkan perkalian antara fluktuasi muka airtanah tahunan, luas wilayah dan spesifik yield. Untuk mengetahui kualitas airtanahnya, dilakukan pengambilan 15 sampel airtanah pada sumur gali. Penentuan lokasi sumur dilakukan secara secara purposive dengan mempertimbangkan kondisi batuan dan kepadatan penduduk, yang lokasinya ditunjukkan pada Gambar 3.

\section{HASIL DAN PEMBAHASAN}

\section{Sistem Akuifer}

Dalam penentuan sistem akuifer, digunakan Peta Geologi dan data hasil pendugaan geolistrik sebagai 
dasar analisis. Dari Peta Geologi diketahui bahwa daerah penelitian tersusun dari formasi aluvium (Qa) dan Formasi Tuf Banten (Qvb). Karakteristik material diketahui berdasarkan analisis penampang yang dihasilkan dari interpolasi titik-titik geolistrik. Melalui pendekatan ini dapat diketahui karakteristik material yang terdapat di bawah titik-titik pendugaan. Hasil analisis dari pendugaan geolistrik menunjukan hasil yang seragam, yaitu memiliki pola perlapisan yang terdiri atas material aluvium, tuf berpasir dan campuran dari kedua material tersebut. Pola perlapisan akuifer teridentifikasi dari pola tahanan jenis yang ditunjukkan masing-masing material, seperti disajikan dalam Tabel 1 .

Berdasarkan Tabel 1, diketahui bahwa tahanan jenis di bawah $5 \Omega \mathrm{m}$ menunjukkan lapisan tuf batupasir. Lapisan tuf batupasir memiliki potensi airtanah rendah. Tuf merupakan batuan yang terbentuk akibat pengendapan dan kompaksi bahan-bahan abu volkanik, sehingga membentuk struktur yang cukup kompak, dengan sedikit pori-pori, tetapi mudah mengalami retakan-retakan. Material ini cenderung memiliki struktur yang lebih kompak daripada material rombakan, ataupun material aluvium. Meskipun demikian, material ini masih mampu menyimpan airtanah karena sebagian materialnya telah mengalami pelapukan, sehingga dapat dikategorikan sebagai material semipermeable. Walaupun masih mampu menyimpan dan melalukan airtanah, namun jumlahnya sangat terbatas. Oleh karena itu material jenis ini dikategorikan sebagai akuitard. Persebaran material batuan ini cenderung mengelompok (di titik pendugaan geolistrik 4 dan 6) dan cenderung memiliki pola kedudukan yang berada diantara dua lapisan akuifer. Kedalamannya berkisar antara 2-15 meter di bawah permukaan tanah dengan ketebalan yang bervariasi. Lapisan batuan berikutnya adalah lapisan campuran antara aluvium dan tuf yang ditunjukkan dengan nilai tahanan jenis 5-7.5 $\Omega \mathrm{m}$. Bercampurnya tuf dengan material aluvium memungkinkan campuran material ini menjadi akuifer karena kemampuan menyimpan dan melalukan air meningkat, sehingga potensi dari akuifer ini dikategorikan sedang. Persebaran lapisan batuan ini merata di seluruh daerah penelitian. Kedalaman lapisan cukup beragam, meskipun secara umum dapat ditemukan dalam rentang kedalaman 1-5 meter dengan ketebalan yang sangat bervariasi. Lapisan ketiga adalah lapisan batuan dengan dengan nilai tahanan jenis $>7,5 \Omega \mathrm{m}$, yang diperkirakan merupakan materal aluvium. Sumber material lapisan ini adalah dari aliran sungai di bagian selatan daerah penelitian yang mengangkut material volkanik dari Formasi Genteng. Melalui sistem sungai, material hasil rombakan dari formasi tersebut terendapkan di daerah dataran rendah secara periodik. Material yang memiliki tekstur pasir berlempung ini memiliki ciri struktur remah dan lepas-lepas (unconsolidated), sehingga terdapat banyak pori yang memungkinkan air tersimpan dan teralirkan. Lapisan yang memiliki potensi airtanah tinggi ini terdapat pada kedalaman yang bervariasi, dari 1-5 m (di titik pendugaan geolistrik 5 dan 7) hingga lebih dari $20 \mathrm{~m}$. Selanjutnya berdasarkan hasil analisis ini dapat ditentukan sistem akuifer di masing masing lokasi geolistrik di daerah penelitian seperti ditunjukkan pada Tabel 2 .
Potensi
Akuifer
Tidak
Tertekan

Seperti telah dikemukakan dalam Metode Penelitian, potensi akuifer tidak tertekan ditentukan dengan cara tumpang susun Peta Kedalaman Muka Airtanah (Gambar 4), Peta Fluktuasi Airtanah (Gambar 5), dan Peta Kualitas Airtanah berdasarkan variasi nilai DHL (Gambar 6). Masing-masing kelas parameter penentu potensi akuifer diberi skor secara hirarki seperti yang ditunjukkan pada Tabel 3, yang kemudian dikelaskan berdasarkan metode aritmatik :

Berdasarkan hasil permintakatan, di daerah penelitian didapatkan tiga kelas potensi akuifer yaitu kelas potensi akuifer tinggi yaitu akuifer dengan kedalaman muka airtanah dangkal, fluktuasi sedang, dan berkualitas baik (tersebar di seluruh Desa Carenang Udik, Gabus, Babakanjaya, Kareo, Junti, Parakan, Majasari, Jawilan, Bojot, dan Pagintungan serta sebagian mencakup desa lainnya), kelas potensi akuifer sedang yaitu akuifer dengan kedalaman muka airtanah dangkal hingga sedang, fluktuasi rendah hingga sedang, dan berkualitas baik (tersebar di sebagian besar Desa Nyompok, serta sebagian desa lain di sekitarnya) dan kelas potensi akuifer rendah yaitu akuifer dengan kedalaman muka airtanah sedang, fluktuasi tinggi dan berkualitas baik (tersebar di bagian selatan Kecamatan Kopo yaitu mencakup Desa Rancasumur, Mekarbaru, Kopo dan desa lain di sekitarnya). Sebaran spasial potensi airtanah di daerah penelitian ditunjukkan pada Gambar 7, sedangkan hasil analisis secara lengkap ditunjukkan pada Tabel 4.

Mencermati Gambar 5, diketahui bahwa sebagian besar daerah penelitian mempunyai potensi akuifer tinggi, sedangkan kelas potensi sedang dan rendah menempati daerah penelitian bagian tenggara. Secara kuantitatif luas potensi akuifer tinggi adalah 52.702.877,70 m2, sedangkan kelas akuifer sedang dan rendah masing-masing seluas 10.506.593,41 $\mathrm{m} 2$ dan 9.857.686,29 m2. Berdasarkan data geolistrik, diketahui bahwa tebal lapisan akuifer pada kelas potensi akuifer tinggi dan rendah adalah $75 \mathrm{~m}$, sedangkan pada kelas potensi akuifer sedang $100 \mathrm{~m}$, sehingga dapat dihitung volume akuifernya sebesar 3.952.715.827,31 m3 untuk kelas potensi akuifer tinggi, 1.050.659.341,00 m3 untuk kelas potensi akuifer sedang dan 739.326.472,10 m3 untuk kelas potensi akuifer rendah. Dengan material akuifer berupa aluvium tuf berpasir, ditentukan nilai spesifik yieldnya sebesar 0,21 , sehingga dapat dihitung ketersediaan airtanahnya yaitu sebesar 830.070.323,7 m3 untuk akuifer kelas potensi tinggi, 220.638.461,7 m3 untuk kelas potensi sedang dan 
155.258.559.10 m3 untuk kelas potensi rendah (Tabel 5).

Memperhatikan Tabel 5 dapat diketahui bahwa fluktuasi rerata muka airtanah tahunan akibat perbedaan musim diakuiferkelas potensitinggiadalah $3 \mathrm{~m}$, sehingga mempunyai batas aman pengambilan 33.202.812,95 m3/tahun. Apabila airtanah akan dimanfaatkan sebagai sumber air minum, dapat dilakukan dengan membuat sumur gali dengan kedalaman 10 hingga $15 \mathrm{~m}$. Hal yang perlu diperhatikan adalah bahwa tebal air dalam sumur harus lebih dari $3 \mathrm{~m}$ karena fluktuasi rata-rata airtanah tahunan sebesar 3 meter Untuk kelas potensi akuifer sedang memiliki fluktuasi muka airtanah tahunan sebesar $5 \mathrm{~m}$, sehingga batas aman pengambilan sebesar 11.031.923,09 m3/ tahun. Cara pengambilan dapat menggunakan sumur gali dengan kedalaman 10 hingga 15 meter dan tebal air di dalam sumur lebih dari 5 $\mathrm{m}$ karena fluktuasi airtanahnya mencapai $5 \mathrm{~m}$. Kelas potensi akuifer rendah memiliki fluktuasi muka airtanah $5 \mathrm{~m}$, sehingga batas aman pengambilan 10.350.570,61 m3/tahun. Untuk mendapatkan airtanah dapat dibuat sumur gali dengan kedalaman $25 \mathrm{~m}$, dan tebal air dalam sumur dijaga sebesar $5 \mathrm{~m}$.

\section{Kualitas Airtanah}

Hasil analisis laboratorium menunjukkan bahwa secara umum kondisi kualitas airtanah di daerah penelitian cukup baik, meskipun untuk

Tabel 2. Sistem akuifer beserta kedalamannya berdasarkan hasil analisis data geolistrik

\begin{tabular}{|c|c|c|c|c|}
\hline $\begin{array}{l}\text { Titik } \\
\text { Pendugaan }\end{array}$ & Lokasi & Tipe Akuifer & Material & Kedalaman $(\mathrm{m})$ \\
\hline \multirow[t]{4}{*}{1} & Desa Bojot & Akuifer tidak tertekan & Campuran & $0.75-4$ \\
\hline & & Akuitard & Tuf batupasir & $4-10$. \\
\hline & & Akuifer semi tertekan & Campuran & $10-150$ \\
\hline & & - & - & - \\
\hline \multirow[t]{3}{*}{2} & Desa Kareo & Akuifer bebas & Aluvium & $0.75-19$ \\
\hline & & Akuifug & Breksi andesit & $19-150$ \\
\hline & & - & - & - \\
\hline \multirow[t]{3}{*}{3} & Desa Dukuh & Akuifer tidak tertekan & Pasir tuf berlempung & $0-11.3$ \\
\hline & & Akuitard & Tuf & $11.3->150$ \\
\hline & & Akuifer semi tertekan & - & - \\
\hline \multirow[t]{3}{*}{4} & Desa Citerep & Akuifer tidak tertekan & Pasir tuf berlempung & $0.75->150$ \\
\hline & & Akuitard & - & - \\
\hline & & Akuifer semi tertekan & - & - \\
\hline \multirow[t]{3}{*}{5} & Desa Sentul & Akuifer tidak tertekan & Pasir tuf berlempung & $4.25->150$ \\
\hline & & Akuitard & - & - \\
\hline & & Akuifer semi tertekan & - & - \\
\hline \multirow[t]{3}{*}{6} & Desa Undarandir & Akuifer tidak tertekan & Aluvium & $1.13->150$ \\
\hline & & Akuitard & - & - \\
\hline & & Akuifer semi tertekan & - & - \\
\hline \multirow[t]{3}{*}{7} & Desa Cigelam & Akuifer tidak tertekan & - & - \\
\hline & & Akuitard & Lempung & $0-100$ \\
\hline & & Akuifer semi tertekan & Batupasir & $100->150$ \\
\hline \multirow[t]{3}{*}{8} & Desa Bumijaya & Akuifer tidak tertekan & - & - \\
\hline & & Akuitard & Tuf & $0-30$ \\
\hline & & Akuifer semi tertekan & Tuf dan aluvium & $30->150$ \\
\hline \multirow[t]{3}{*}{9} & Desa Kebonratu & Akuifer tidak tertekan & Pasir tuf berlempung & $0-2.46$ \\
\hline & & Akuitard & Tuf & $2.46->150$ \\
\hline & & Akuifer semi tertekan & - & - \\
\hline \multirow[t]{3}{*}{10} & Desa Kamaruton & Akuifer tidak tertekan & Pasir tuf berlempung & $0->150$ \\
\hline & & Akuitard & - & - \\
\hline & & Akuifer semi tertekan & - & - \\
\hline
\end{tabular}




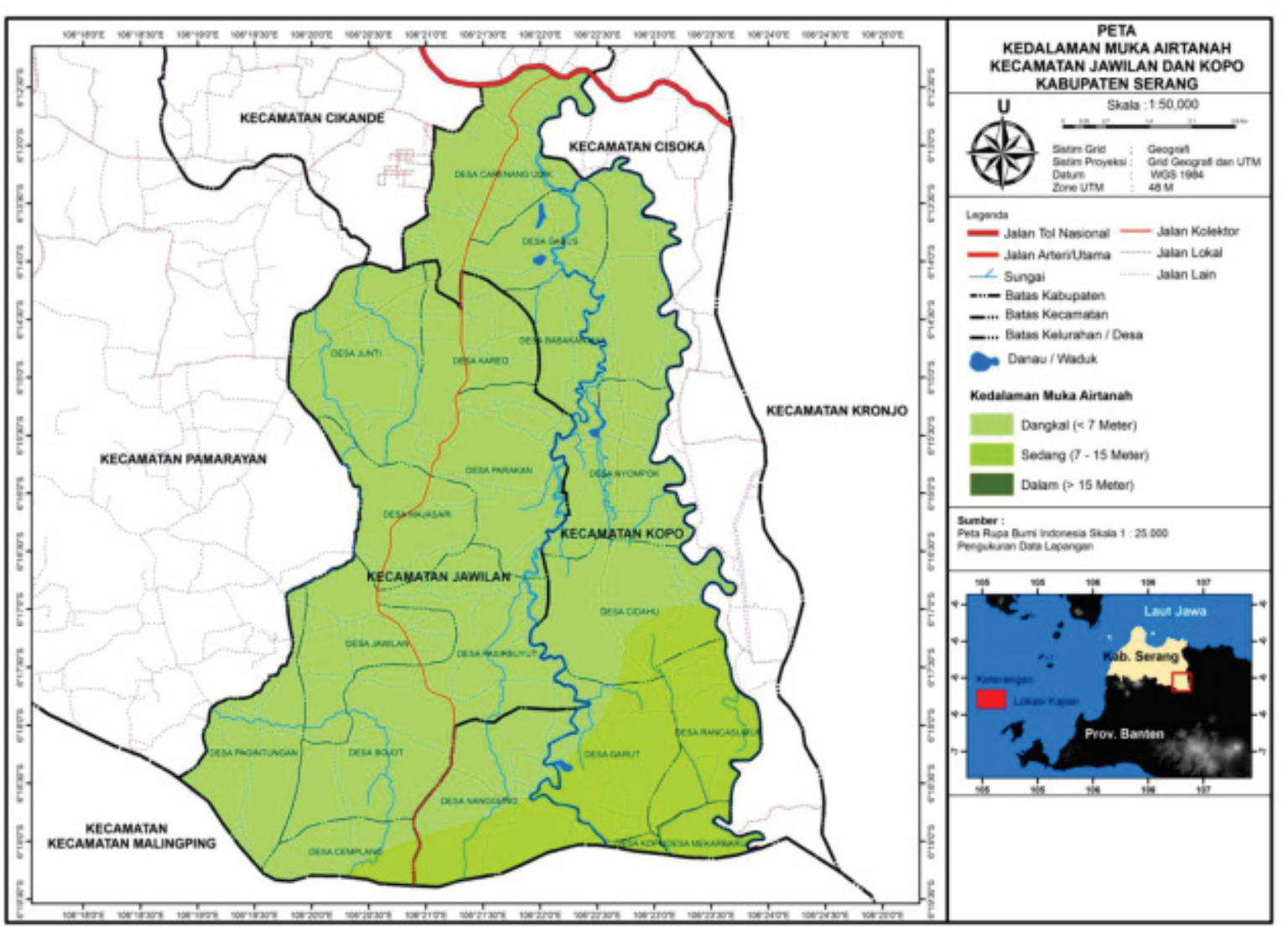

Gambar 4. Kedalaman muka airtanah

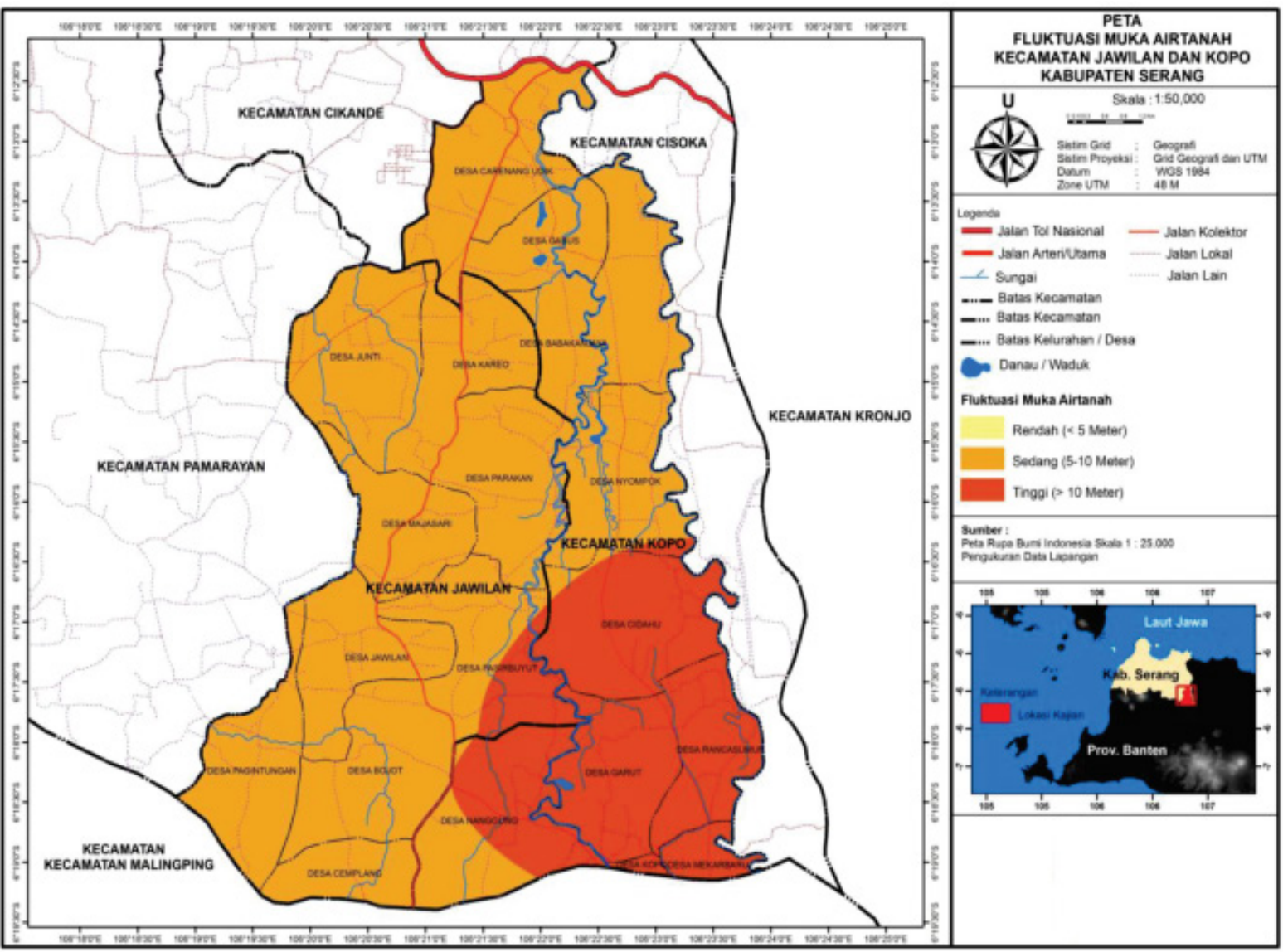

Gambar 5. Fluktuasi muka airtanah 


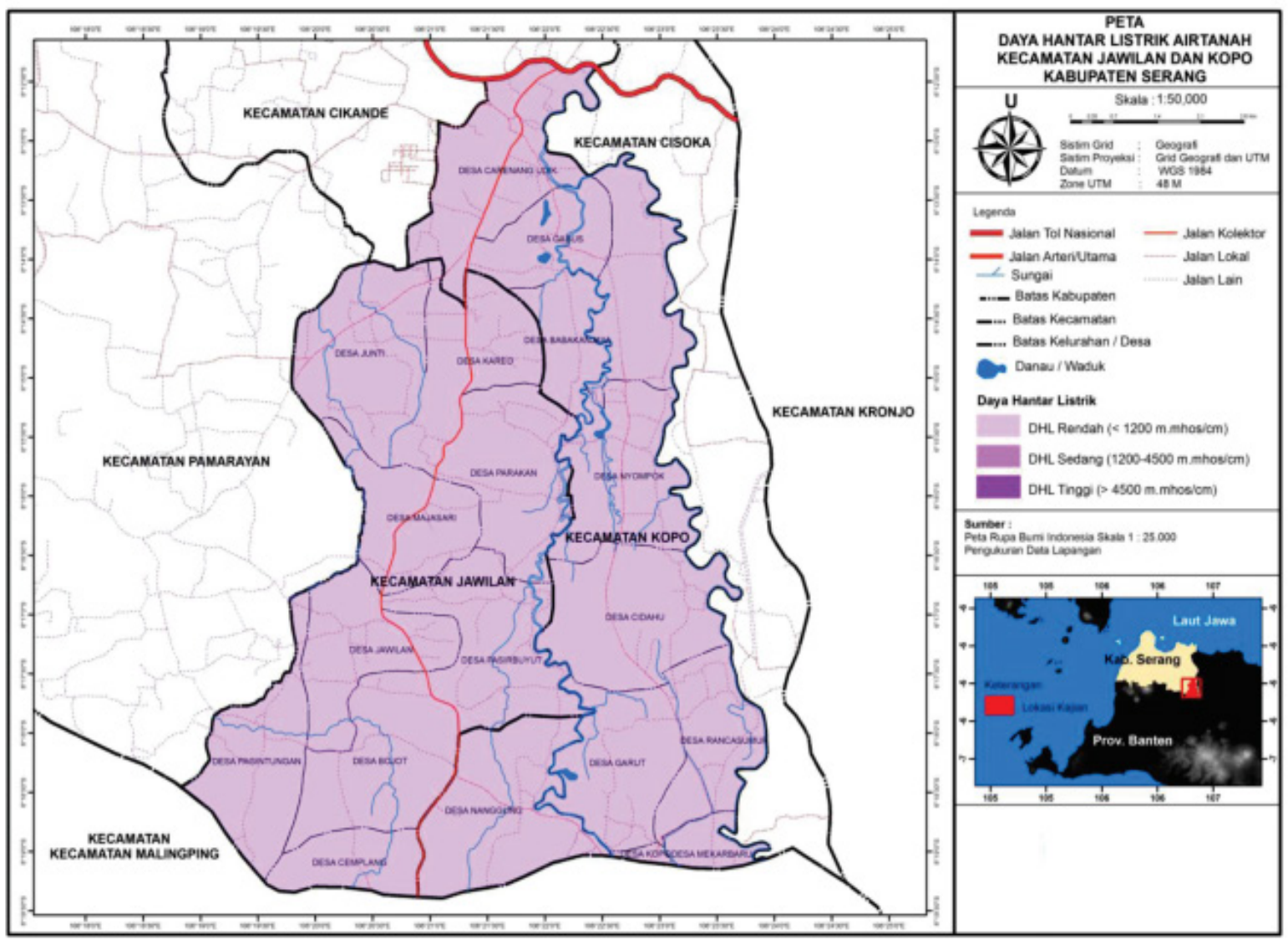

Gambar 6. Daya hantar listrik airtanah

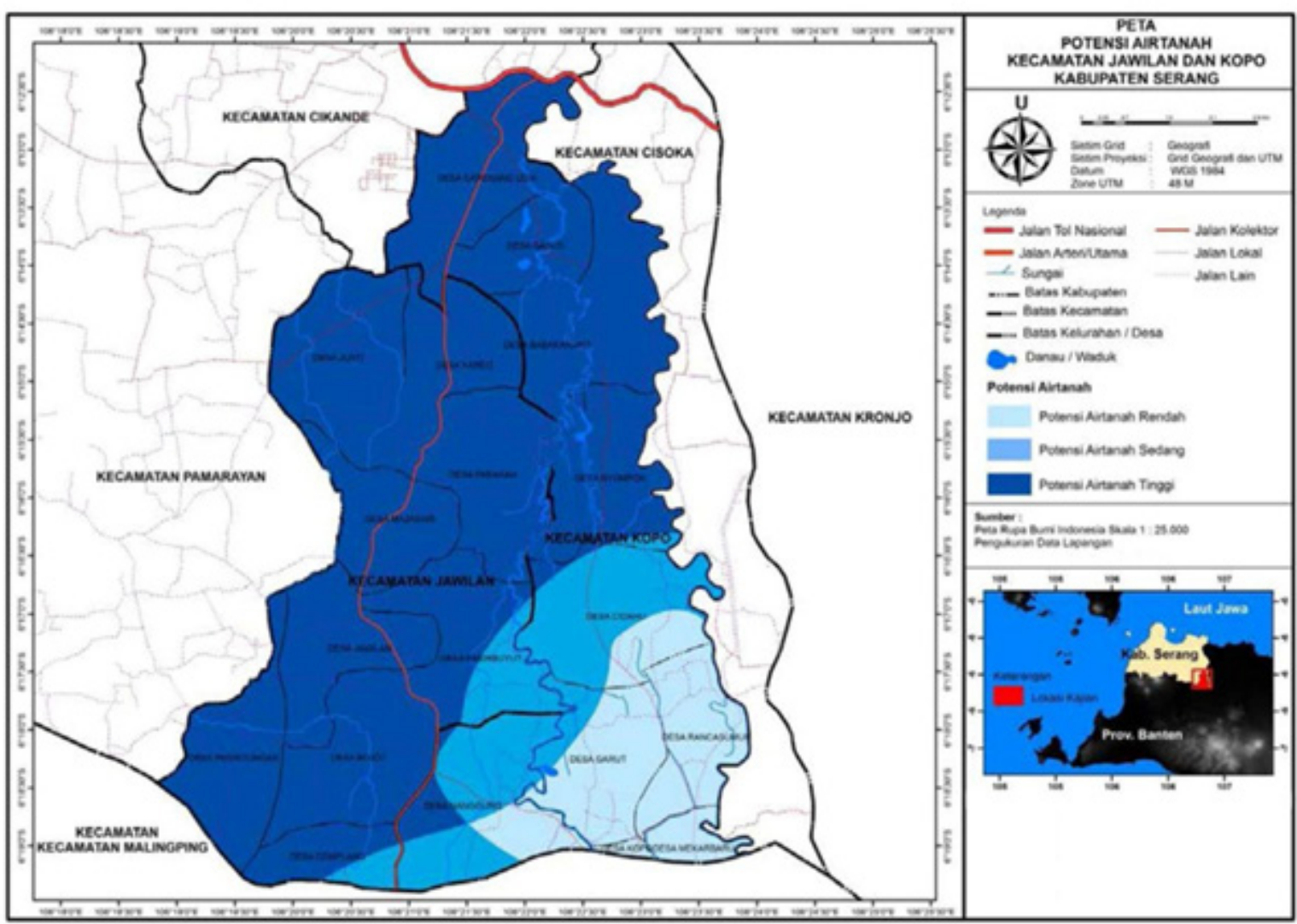

Gambar 7. Potensi airtanah pada akuifer tidak tertekan 


\begin{tabular}{llll}
\hline \multicolumn{3}{c}{ Tabel 3. Penentuan potensi akuifer tidak tertekan } \\
\hline $\begin{array}{l}\text { Kelas Kedala- } \\
\text { man }\end{array}$ & Kode (D) & $\begin{array}{l}\text { Kedalaman } \\
\text { Muka Air- } \\
\text { tanah }(\mathrm{m})\end{array}$ & Skor \\
\hline Dangkal & D1 & $<7$ & 3 \\
Sedang & D2 & $7-15$ & 2 \\
Dalam & D3 & $>15$ & 1 \\
Kelas Fluktuasi & Kode (F) & Fluktuasi Air- & Skor \\
Muka Airtanah & & tanah (m) & \\
Rendah & F1 & $<2$ & 3 \\
Sedang & F2 & $2-5$ & 2 \\
Tinggi & F3 & $>5$ & 1 \\
Kelas Kualitas & Kode & Nilai DHL & Skor \\
Air & $(M)$ & $(\mu$ mhos/cm) & \\
Baik & M1 & $<1200$ & 3 \\
Sedang & M2 & $1200-4500$ & 2 \\
Buruk & M3 & $>4500$ & 1 \\
\hline Suber: Hasil Ann & &
\end{tabular}

Sumber: Hasil Analisis

continue...table 4

\begin{tabular}{|c|c|c|c|}
\hline $\begin{array}{l}\text { rendah } \\
6.7\end{array}$ & D2 F3 M1 & $\begin{array}{l}\text { Muka } \\
\text { airtanah } \\
\text { umumnya } \\
\text { memiliki } \\
\text { keda- } \\
\text { laman } \\
\text { sedang, } \\
\text { fluktuasi } \\
\text { tinggi, } \\
\text { dan } \\
\text { berkuali- } \\
\text { tas baik }\end{array}$ & $\begin{array}{l}\text { Seluruh Desa } \\
\text { Rancasumur, } \\
\text { Mekarbaru, } \\
\text { Kopo } \\
\text { Sebagian kecil } \\
\text { Desa Cida- } \\
\text { hu,Nanggung } \\
\text { Sebagian Desa } \\
\text { Garut }\end{array}$ \\
\hline
\end{tabular}

\section{Sumber : hasil analisis}

kadar kalsium, magnesium, BOD dan COD telah melampaui baku mutu di beberapa sampel (Tabel 6).

Mencermati Tabel 6, diketahui bahwa kadar kalsium pada sampel air di Desa Cidahu telah mencapai $105 \mathrm{mg} / \mathrm{l}$. Menurut Todd dan Mays (2005), kadar kalsium sebesar ini tergolong tinggi. Untuk magnesium, kadarnya juga tergolong tinggi di semua sampel airtanah karena lebih dari $50 \mathrm{mg} / \mathrm{l}$. Kadar magnesium di atas $50 \mathrm{mg} / \mathrm{l}$ dalam air minum dapat menyebabkan efek laksatif. Untuk kalium, dari 15 sampel airtanah yang diambil, semuanya mempunyai kadar di bawah $50 \mathrm{mg} / \mathrm{l}$. Hal ini menunjukkan bahwa kandungan kalium di daerah penelitian masih dalam kondisi baik. Kondisi serupa juga diketemukan pada kandungan natrium. Hasil analisis laboratorium menunjukkan bahwa kandungan natrium sampel yang diambil semuanya masih di bawah baku mutu. Untuk bikarbonat, dari 15 sampel airtanah yang diambil, semua sampel menunjukkan kualitas air yang masih baik karena tidak ada yang melebihi baku mutu. Ditinjau dari kadar kloridanya, semua sampel juga berada dalam kondisi baik secara kualitas. Hal ini juga sesuai dengan hasil pengukuran DHL yang menunjukkan nilai DHL yang rendah. Baku mutu air Peraturan Menteri Kesehatan Nomor 492 Tahun 2010 mensyaratkan kadar klorida tidak boleh melebihi $250 \mathrm{mg} / \mathrm{l}$ apabila air akan digunakan sebagai sumber air minum. Ditinjau dari kadar besi dan mangannya, baku mutu air Peraturan Menteri Kesehatan Nomor 492 Tahun 2010 mempersyaratkan bahwa apabila air akan digunakan sebagai sumber air minum, kadar besinya tidak boleh melebihi $0,3 \mathrm{mg} / \mathrm{l}$ dan kadar mangannya tidak boleh melebihi $0,4 \mathrm{mg} / \mathrm{l}$. Seperti halnya besi, mangan yang tinggi pada air juga menyebabkan berkurangnya kejernihan air (berwarna coklat kemerahan), menyebabkan rasa dan bau air yang khas serta noda karat pada pakaian atau peralatan mandi yang dicuci dengan air tersebut. Hasil analisis sampel air menunjukkan semua sampel mengandung besi total dan mangan di bawah baku mutu. UntukBOD, hasil analisis sampel airtanah menunjukkan hanya satu sampel yang memiliki nilai BOD di atas baku mutu yaitu di Desa Mekarbaru yaitu sebesar 
Ig.L.Setyawan Purnama /Majalah Geografi Indonesia, Vol. 33 No.1, Maret 2019 : 16 - 24

\begin{tabular}{llll}
\hline \multicolumn{2}{c}{ Tabel 5. Ketersediaan dan hasil aman pengambilan airtanah pada akuifer tidak tertekan } \\
\cline { 2 - 4 } Parameter & \multicolumn{1}{c}{ Tinggi } & \multicolumn{1}{c}{ Kelas Potensi Akuifer } \\
\cline { 2 - 4 } & $52.702 .877,70$ & $10.506 .593,41$ & Rendah \\
\hline Luas permintakan (m2) & 75 & 100 & 75 \\
Tebal rerata akuifer (m) & $3.952 .715 .827,31$ & $1.050 .659 .341,00$ & $739.326 .472,10$ \\
Volume akuifer (m3) & Aluvium tuf berpasir & Aluvium tuf berpasir & Aluvium tuf berpasir \\
Material penyusun & 0.21 & 0.21 & 0.21 \\
Spesifik yield & $830.070 .323,7$ & $220.638 .461,7$ & 155.258 .559 .10 \\
Ketersediaan airtanah (m3) & 3 & 5 & 5 \\
Fluktuasi rerata tahunan (m) & $33.202 .812,95$ & $11.031 .923,09$ & $10.350 .570,61$ \\
Hasil aman (m3/tahun) & Sumur gali 10-15 m & Sumber gali 10 -15 m & Sumur gali >25 \\
Kedalaman pengambilan airtanah $(\mathrm{m})$ & & & \\
\hline
\end{tabular}

Sumber: Hasil perhitungan dan analisis

Tabel 6. Kadar unsur-unsur kimia pada sampel airtanah di daerah penelitian

\begin{tabular}{|c|c|c|c|c|c|c|c|c|c|c|c|}
\hline No. & $\begin{array}{c}\mathrm{Ca}^{2-} \\
(\mathrm{mg} / \mathrm{l})\end{array}$ & $\begin{array}{c}\mathrm{Mg}^{2+} \\
(\mathrm{mg} / \mathrm{l})\end{array}$ & $\begin{array}{c}\mathrm{Na}^{+} \\
(\mathrm{mg} / \mathrm{l})\end{array}$ & $\begin{array}{c}\mathrm{K}^{+} \\
(\mathrm{mg} / \mathrm{l})\end{array}$ & $\begin{array}{l}\mathrm{HCO}_{3}{ }^{-} \\
(\mathrm{mg} / \mathrm{l})\end{array}$ & $\begin{array}{l}\mathrm{SO}_{4}^{2-} \\
(\mathrm{mg} / \mathrm{l})\end{array}$ & $\begin{array}{c}\mathrm{Cl}^{-} \\
(\mathrm{mg} / \mathrm{l})\end{array}$ & $\begin{array}{c}\text { Fe Total } \\
(\mathrm{mg} / \mathrm{l})\end{array}$ & $\begin{array}{c}\mathrm{Mn}^{2-} \\
(\mathrm{mg} / \mathrm{l})\end{array}$ & $\begin{array}{c}\mathrm{BOD} \\
(\mathrm{mg} / \mathrm{l})\end{array}$ & $\begin{array}{c}\text { COD } \\
(\mathrm{mg} / \mathrm{l})\end{array}$ \\
\hline 1 & 95 & 52,3 & 5,31 & 7,45 & 26,0 & 50,9 & 65 & 0,0148 & 0,0003 & 0,63 & 1,81 \\
\hline 2 & 75 & 59,6 & 7,00 & 7,79 & 9,6 & 47,7 & 50 & $\leq 0,001$ & 0,0023 & 0,87 & 1,58 \\
\hline 3 & 95 & 52,3 & 4,97 & 8,22 & 14,4 & 18,7 & 90 & 0,0193 & $\leq 0,001$ & 1,31 & 4,06 \\
\hline 4 & 80 & 77,8 & 5,00 & 7,45 & 12,8 & 18,9 & 85 & 0,0095 & $\leq 0,001$ & 0,58 & 4,29 \\
\hline 5 & 95 & 66,9 & 4,01 & 8,28 & 6,0 & 10,2 & 85 & 0,0072 & $\leq 0,001$ & 0,58 & 3,61 \\
\hline 6 & 70 & 80,3 & 4,93 & 5,39 & 18,8 & 8,7 & 100 & 0,0034 & $\leq 0,001$ & 1,11 & 2,03 \\
\hline 7 & 80 & 87,6 & 5,32 & 5,68 & 19,2 & 23,4 & 70 & 0,0049 & 0,0834 & 0,15 & 0,68 \\
\hline 8 & 90 & 90,0 & 7,00 & 5,10 & 17,2 & 4,7 & 7 & 0,0042 & $\leq 0,001$ & 1,16 & 1,16 \\
\hline 9 & 70 & 80,3 & 4,97 & 7,06 & 16,4 & 1,0 & 90 & 0,0026 & $\leq 0,001$ & 2,17 & 2,17 \\
\hline 10 & 60 & 97,3 & 5,00 & 8,28 & 19,2 & 1,3 & 85 & 0,0064 & $\leq 0,001$ & 0,58 & 0,58 \\
\hline 11 & 75 & 71,7 & 4,10 & 8,28 & 7,6 & 10,9 & 95 & 0,0170 & $\leq 0,001$ & 0,43 & 0,43 \\
\hline 12 & 105 & 51,2 & 4,93 & 6,50 & 18,8 & 24,1 & 85 & 0,0072 & $\leq 0,001$ & 0,29 & 0,29 \\
\hline 13 & 75 & 71,7 & 4,32 & 5,52 & 61,2 & 207,2 & 95 & 0,0049 & $\leq 0,001$ & 0,15 & 0,45 \\
\hline 14 & 70 & 68,1 & 4,46 & 8,28 & 45,2 & 131,2 & 85 & 0,0064 & 0,1635 & 1,74 & 13,77 \\
\hline \multirow[t]{2}{*}{15} & 70 & 55,9 & 3,54 & 4,00 & 13,2 & 12,2 & 80 & 0,0079 & 0,0266 & 0,09 & 0,23 \\
\hline & $100^{\circ}$ & $50^{\circ}$ & $200^{a}$ & $50^{\circ}$ & $500^{\circ}$ & $250^{2}$ & $250^{4}$ & $0,3^{2)}$ & $0,4^{2}$ & $2^{\mathrm{s})}$ & $10^{3)}$ \\
\hline
\end{tabular}

a) Peraturan Menteri Kesehatan Nomor 492/MENKES/PER/V/2010

b) Peraturan Pemerintah Nomor 82 Tahun 2001(Kriteria Mutu Air Kelas I)

c) Menurut D.K.Todd dan L.W.Mays Tahun 2005

2,17 mg/l. Baku mutu air untuk air minum Peraturan Pemerintah Nomor 82 Tahun 2001 mensyaratkan 2,0 $\mathrm{mg} / \mathrm{l}$ sebagai batas maksimum kadar BOD dalam air. Demikian pula untuk COD, terdapat 1 sampel air yang kadarnya melebihi baku mutu yaitu sampel air di Desa Babakanjaya dengan kadar COD 13,77 $\mathrm{mg} / \mathrm{l}$. Baku mutu air untuk air minum Peraturan Pemerintah Nomor 82 Tahun 2001 mensyaratkan 10 $\mathrm{mg} / \mathrm{l}$ sebagai batas maksimum kadar COD dalam air.

\section{KESIMPULAN}

Di daerah penelitian ditemukan adanya akuifer tidak tertekan dengan material batuan berupa aluvium dan tuf serta akuifer semi tertekan dengan material batuan berupa campuran aluvium, tuf, dan batupasir. Diantara kedua akuifer tersebut dijumpai akuitard berupa tuf batupasir.

Berdasarkan hasil perhitungan, diketahui bahwa ketersediaan airtanah pada akuifer tidak tertekan di daerah penelitian sebesar
1.205.967.345 $\mathrm{m} 3$, dengan hasil aman pengambilan airtanah sebesar $\quad 54.585 .307 \quad \mathrm{~m} 3 /$ tahun.

Ditinjau dari kualitasnya, secara umum kondisinya cukup baik, meskipun untuk kadar kalsium, magnesium, BOD dan COD telah melampaui baku mutu pada beberapa sampel.

\section{UCAPAN TERIMA KASIH}

Ucapan terima kasih disampaikan kepada Achmad Cahyadi, S.Si., M.Sc dan Lili Ismangil, S.E yang telah membantu dalam pengumpulan data di lapangan.

\section{DAFTAR PUSTAKA}

Fenta A A \& Kifle A. (2014). Spatial Analysis of Groundwater Potential Using Remote Sensing and GIS-Based Multi-Criteria Evaluation in Raya Valley, Nothern Ethiopia. Hydrogeology Journal 23 (2015) : 195-206.

Fontana M., Grassa F., Cuisimano G \& Favara R. (2008). Geochemistry and Potential Use of Groundwater in The Rocca Busambra Area (Sicily, Italia). Environ Geol 57 (2016) : 885-898. 
Kumar T., Gautam A K \& Jhariya D C. (2016). MultiCriteria Decision Analysis for Planning and Management of Groundwater Resources in Balod District, India. Environ Earth Sci 75(649) : 1- 16. Moench, A.F and Barlow, P.M. (2000). Aquifer Response to Stream-Stage and Recharge Variations. I. Analytical Step-Response Functions. Journal of Hydrology 230 (2000) : 192-2010.

Naghibi S A \& Pourghasemi H A. (2015). GIS-Based Groundwater Potential Mapping Using Boodted Regression Tree, Classification and Regression Tree and Random Forest Machine Learning Models in Iran. Environ Monit Asses 188 (44) : 1-25.

Purnama S. (2008). The Potential of Rainfall and Its Impact to Groundwater Storage in Java Island. Indonesian Journal of Geography 40 (2) : 153-166.

Purnama S. (2010). Hidrologi Air Tanah. Kanisius, Yogyakarta.

Purnama S \& Marfai M A. (2012). Saline Water Intrusion toward Groundwater : Issues and its Control. Journal of Natural Resources and Development 2012 (02) : 25-32.

Purnama S. (2017). Dinamika Kedudukan Interface di Pesisir Kabupaten Kebumen, Jawa Tengah. Majalah Geografi Indonesia 31 (2) : 1-7.

Richards K., Revil A., Jardani A., Henderson F., Batzle M \& Haas A. (2010). Pattern of Shallow Groundwater Flow at Mount Princeton Hot Springs, Colorado, Using Geoelectrical Methods. Journal of Volcanology and Geothermal Research 198 (2010) 2017-232.
Rushton, K.R. (2003). Groundwater Hydrology : Conceptual and Computational Models. John Wiley \& Sons Ltd, The Atrium, Southern Gate, Chichester, West Sussex Todd, D.K. and L.W. Mays. (2005). Groundwater Hydrology. John Wiley \& Sons, New York. Wamalwa AM., Serpa L F \& Doser D I. (2011). Investigations of Groundwater Flow Assosiated with The Saratoga Warm Springs and The Tecopa Hot Springs Near Death Valley, California, Using Magnetic and Conductivity Methods. Tectonophysics 502 (2011) : 267-275.

WaikarML\&NilawarAP.(2014).Identification ofGroundwater Potential Zone Using Remote Sensing and GIS Technique. International Journal of Innovative Research in Science Engineering and Technology 3 (5) : 12163-12174.

Zohdy A.A.R, Eaton G.P and Mabey D.R. (1980). Application of Surface Geophysics to Groundwater Investigation. Washington : United States Department of The Interior. 